\title{
Diversity, Length-Weight Relations, and Condition Factor of Sea Cucumbers in Three Coastal Areas Along the Southern Coast of Sri Lanka
}

\section{Lalith Kumara Thiththagalle Gamage ${ }^{1,4}$, Gajahin Gamage Nadeeka Thushari², Keerthi Sri Senarathna Atapaththu ${ }^{3}$, Hewa Kondaramage Rasika Sampath Kumara ${ }^{1}$, Jayan Duminda Mahesh Senevirathna ${ }^{2, *}$}

\author{
${ }^{1}$ University of Colombo, Institute for Agro-Technology and Rural Sciences, Weligatta-New Town, Hambantota, 82004, Sri \\ Lanka. \\ ${ }^{2}$ Uva Wellassa University, Faculty of Animal Science and Export Agriculture, Department of Animal Science, Passara Road, \\ Badulla, 90000, Sri Lanka. \\ ${ }^{3}$ University of Ruhuna, Faculty of Fisheries and Marine Sciences \& Technology, Department of Limnology and Water \\ Technology, Wellamadama, Matara, 81000, Sri Lanka. \\ ${ }^{4}$ University of Ruhuna, Faculty of Allied Health Science, Karapitiya, Galle, 80000, Sri Lanka.
}

\section{How to cite}

Gamage, L.K.T., Thushari, G.G.N., Atapaththu, K.S.S., Kumara, H.K.R.S., Senevirathna, J.D.M. (2021). Diversity, Length-Weight Relations, and Condition Factor of Sea Cucumbers in Three Coastal Areas Along the Southern Coast of Sri Lanka. Turkish Journal of Fisheries and Aquatic Sciences, 21, 575-588. http://doi.org/10.4194/13032712-v21_12_01

\section{Article History}

Received 31 December 2021

Accepted 04 August 2021

First Online 11 August 2021

Corresponding Author

Tel.: +817015781225

E-mail: duminda@uwu.ac.lk

\section{Keywords}

Holothuroidea

Length-Weight Relationship

Allometric Growth Pattern

Condition Factor

Fishery Management

\begin{abstract}
Economically and ecologically important ecosystems that consist of diverse finfish and shellfish resources are found along the southern coast of Sri Lanka. Thus, the current study intends to assess the species diversity, length-weight (L-W) relationships, and condition factor of sea cucumber stocks in selected coastal sites of southern Sri Lanka. The diversity of sea cucumber species was surveyed using the systematic sampling technique in three selected sites (Bandaramulla, Mirissa, and Weligama) during February-December 2019. The growth pattern of each species was identified using a least-squares regression model computed for length-weight relationships. Fulton's condition factor (K) was analyzed for each species. There were four common sea cucumber species (Holothuria atra - Lolly Fish, Bohadschia marmorata - White Thread fish, Actinipyga miliaris - Deep Water Blackfish, and Thelenota ananas - Prickly Redfish) in study sites, with Holothuria atra and Bohadschia marmorata were recorded as the most abundant species. The length-weight relationship derived for the above four species exhibited a negative allometric growth pattern (" $b$ " $<$ " 3 "), indicating faster length increment compared to weight. The habitat qualities of all sea cucumber species were in optimum environmental condition. Our findings would benefit as baseline data for implementing sustainable management practices of sea cucumber resources.
\end{abstract}

\section{Introduction}

Sea cucumbers (Class Holothuroidea of the Phylum Echinodermata) play a significant role as a biotic component in the benthic zone of coastal and marine ecosystems (Gonzalez-Wangüemert et al., 2014). These holothurians possess an orally-aborally elongated body with a pentaradial symmetry, a unique morphological character of Phylum Echinodermata. Further, they show deposit and filter-feeding mechanisms. They play a unique ecological role in maintaining the natural equilibrium of the ecosystem by controlling micro-algae growth, recycling nutrients, and mixing the upper sediment layers while contributing as a significant commercial resource for coastal livelihood (Francour, 1997; Gonzalez-Wangüemert et al., 2014; MacTavish et al., 2012; Uthicke, 2010). The biological characteristics of holothurians provide diverse commercial values for human wellbeing. Sea cucumbers are used in traditional medicine in most Asian countries, while this resource is used to extract different therapeutic compounds such as bioactive peptides, triterpene glycosides, amino acids, 
chondroitin sulphates, carotenoids, vitamins, minerals, gelatines, fatty acids, and collagens (Pangestuti \& Arifin, 2018). Recently, the health effects and therapeutic benefits of sea cucumbers such as antitumor, antimicrobial, antioxidant, neuroprotective, anticoagulant properties, and wound healing potentials have been scientifically confirmed through research studies and investigations while these functional medicinal compounds are popular in the biomedicine sector (Pangestuti \& Arifin, 2018).

Sea cucumbers play a significant role as nutritional food sources worldwide, and thus, around 66 sea cucumber species are commercially harvested by more than 40 countries. A high demand exists in the international market for processed (boiled and dried forms) holothurians (Conand \& Byrne, 1993; Purcell, 2010; Purcell et al., 2012a, b). Apart from the international trade, sea cucumbers are locally consumed by the residents in the countries such as Chinese heritage in Indonesia, Papua New Guinea, Fiji island, and Malaysia (Conand \& Byrne, 1993).

Based on the literature records, the annual total global production of sea cucumbers as live animals is approximately 100,000 tonnes (Purcell, 2010; Purcell et al., 2012a). Sea cucumber fishery in tropical regions contributes to global production (GonzálezWangüemert et al., 2014). Sea cucumber harvesting industry in these zones are often artisanal, and fishers exploit sea cucumbers during low tide period or freedive on shallow coastal reefs for more than one century with the boom-and-bust fashion (Conand \& Byrne, 1993). However, sea cucumber fishery in temperate coastal regions has developed and expanded recently, while fishermen target single species for exploitation. Further, the aforesaid fishery sector in the temperate zone is industrialized with novel fishing technology such as large boats and sophisticated fishing gear for exploitation from deep-sea waters (GonzalezWangüemert et al., 2014).

According to the literature records, targeted holothurian species are overexploited by exceeding maximum sustainable yield in almost all parts of the world (Anderson et al., 2011; Purcell, 2010). A recent scientific investigation reported that the percentage of overexploited, under the level of full exploitation with no potential margin for expansion, depleted and moderately or under-exploited are $38 \%, 14 \%, 20 \%$, and $27 \%$, respectively (Purcell et al., 2013). In most countries, the increasing market demand for sea cucumber products, unsustainable fishery management practices, and irresponsible exploitation activities are significant factors affecting overexploitation of sea cucumber fishery stocks (Conand, 2000; Conand, 2004).

Holothurians are especially susceptible to overharvesting due to their life-history traits, such as long lifespan, lower and irregular recruitment process, late age at their maturity, slow growth rate, and densitydependent reproductive mechanism (Uthicke et al., 2004). Hence, sea cucumber fishery requires conservation and management concerns due to the vulnerable factors for overexploitation, such as marketable capacity and unique biological traits (Purcell, 2010). Therefore, the long-term sustainability of the sea cucumber fishery sector is vital for continuous commercial benefits to coastal communities. FAO (2011) strongly recommends respective countries adopt appropriate management and conservation measures considering the scientific information to maintain the sea cucumber harvest at levels of maximum sustainable yield.

In Sri Lanka, 21 sea cucumber species have been identified as economically important fishery resources out of 75 well-known species mainly found along the coastal intertidal zones of Sri Lanka (Clark \& Rowe, 1971; Dissanayake \& Stefanson, 2010). Sea cucumber production is primarily recorded from the north, east, and north-west coastal regions of Sri Lanka (Veronika et al., 2018). Like the global context, local sea cucumber resources are highly vulnerable to depletion according to the existing population dynamic data (Dissanayake \& Wijeyaratne, 2007). As the initial step of management of local holothurians, a detailed investigation on the length-weight relationship of four common sea cucumber species: Holothuria spinifera, Bohadschia marmorata, Stichopus naso, and Holothuria atra, has been conducted from the commercial harvest of northeastern coastal waters of Sri Lanka during May 2014 to September 2016 (Veronika et al., 2018). However, only limited published scientific information is available on basic species diversity information and population dynamic aspects, including the length-weight relationship of sea cucumbers from coastal waters around the southern part of Sri Lanka. Therefore, considering the factors described above of these commercially important species, the present study aimed to fill this research gap by selecting the southern coastal region of Sri Lanka.

The current work expects to provide a clear insight into the basic scientific information of sea cucumber species in the selected coastal habitats of the southern province of Sri Lanka. It is a preliminary approach aiming to provide an overview of reliable scientific data for the sustainable management of sea cucumbers. Accordingly, this study has three primary objectives: (i) to assess the current diversity status of the identified, commercially important sea cucumber species, (ii) to analyze the length-weight relationships and growth pattern of identified, commercially important sea cucumber stocks, and (iii) to calculate the condition factor of identified sea cucumber stocks in different coastal zones of the southern province of Sri Lanka. Assessment of the species diversity and basic population dynamics of sea cucumber stocks help provide the baseline information in identifying conservation approaches and implementing fishery management practices toward the sustainable utilization of this economically important aquatic resource. 


\section{Materials and Methods}

This study consists of two phases: (i) determining the species diversity status of commercially important common sea cucumbers, and (ii) analysis of morphometric measurements with great importance in fishery assessments of aquatic species and condition factor which acts as an indicator on the quality of their living environment (Garcia et al., 1989; Haimovici \& Velasco, 2000; Le-Cren, 1951) along the southern coast of Sri Lanka.

\section{Study Sites and Sampling}

Three study sites (i.e., Bandaramulla: $80^{\circ} 27^{\prime} 56 \mathrm{E}$, $5^{\circ} 56^{\prime} 31 \mathrm{~N}$, Mirissa: $80^{\circ} 27^{\prime} 44 \mathrm{E}, 5^{\circ} 5635^{\prime \prime} \mathrm{N}$, and Weligama: $\left.80^{\circ} 27^{\prime} 46 \mathrm{E}, 5^{\circ} 5638^{\prime \prime} \mathrm{N}\right)$ were selected during a preliminary survey by considering the commercial value and ecological characteristics of the coastal zone belonging to the southern province of Sri Lanka (Figure 1). Sample collection was carried out monthly from February-December 2019. A species diversity survey was conducted for each sampling site,
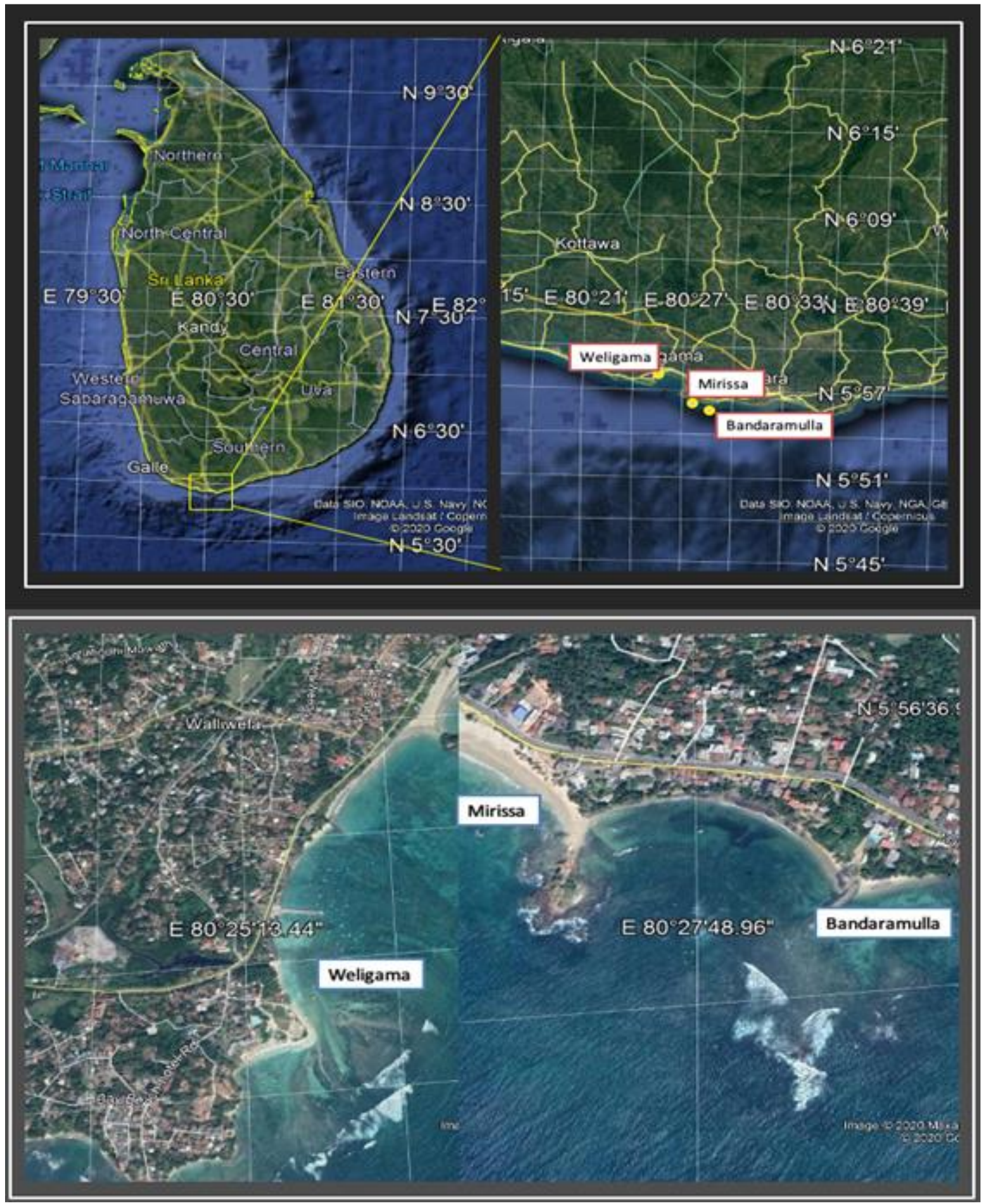

Figure 1. Study sites in the southern coastal zone of Sri Lanka (Google Earth Pro, 2020 - https://www.google.com/earth/ , “Accessed $25^{\text {th }}$ April 2020"). 
using a systematic sampling technique by positioning quadrat $(1 \mathrm{~m} \times 1 \mathrm{~m})$ as sampling units at $10 \mathrm{~m}$ intervals along a $100 \mathrm{~m}$ long main transect line (east-west direction). The sampling unit represents all sea cucumbers present within the quadrat. During sampling, sea cucumbers were collected with divers' support by surveying a minimum of three transects representing all substrates: sandy bottom, seagrass meadows, and shallow rocky patches found in study locations (FuenteBetancourt et al., 2001; Lampe-Ramdoo et al., 2014). The sampling process of holothurians was convenient at any of these shallow sites.

\section{Sample Analysis for the Species Diversity Assessment and Data Collection}

Collected sea cucumber samples were subjected to in-situ analysis. Different sea cucumber species were identified using recommended external morphological characters, pictorial guides, and related scientific information in the literature records (Hendler et al., 1995; Veronika et al., 2018). After identification, the number of individuals belonging to each species in each study site was counted separately for each site. The relative abundance of each sea cucumber species within the three regions was calculated using the standard formula given below (equation 1).

\section{Equation 1;}

$$
\text { Relative Abundance }=\frac{\begin{array}{c}
\text { Total number of individuals of } \\
\text { particular species }
\end{array}}{\begin{array}{c}
\text { Total number of } \\
\text { individuals of all species }
\end{array}}
$$

Different substrate characteristics (e.g., sandy, seagrass, and rocky bottom) of the surveyed area in each sampling site were also recorded to identify suitable habitat types of different species. ShannonWiener index $\left(\mathrm{H}^{\prime}\right)$ (equation 2) helped to estimate the diversity of sea cucumber species of each study site

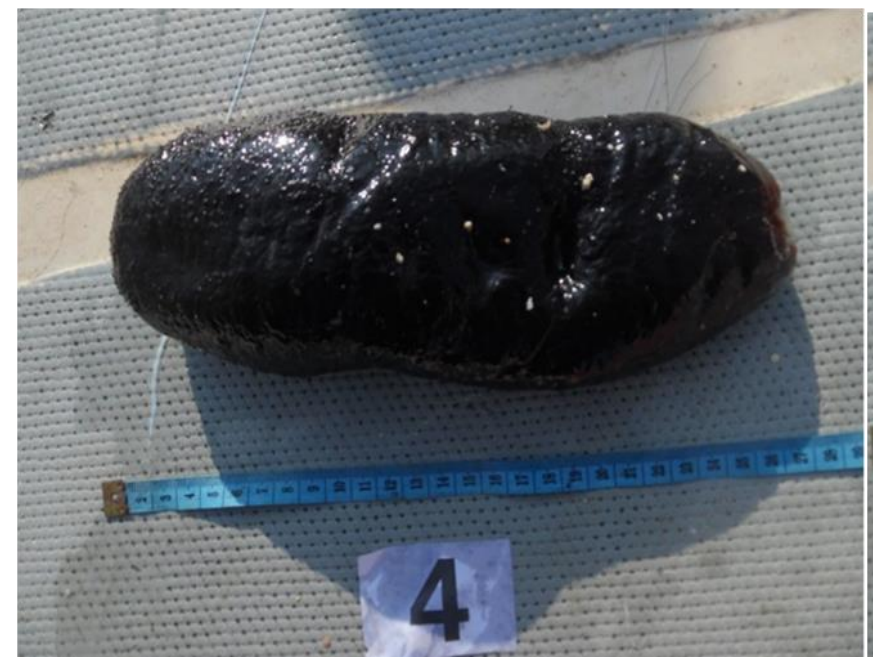

Figure 2. Length measurement of identified sea cucumber species.
(Magurran, 2004; Morris et al., 2014).

Equation 2;

$$
H^{\prime}=-\sum_{1}^{i} p_{i} \ln p_{i}
$$

Where pi - Proportion ( $n / N)$ of individuals of one species found $(n)$ divided by the total number of individuals found $(N)$

\section{Determination of the Length-Weight Relationship and Condition Factor}

After identifying the sea cucumber species, samples were allowed to drain for a minimum of two minutes before subjecting to the length-weight measurements (Veronika et al., 2018). The total length (L) and weight (W) of individuals belonging to each species in different sites were measured using the measuring tape and a digital balance (UNISTAR SF-400), respectively. The length was measured dorsally from the anus to the center of the tentacle crown with an accuracy of $1 \mathrm{~mm}$ (Figure 2), while the weight was measured to the nearest $1 \mathrm{~g}$.

The length-weight relationship was estimated using the power function (equation 3 and 4) described by Pauly (1980) to identify the relative changes in the morphology of sea cucumber species.

Equation 3;

$$
Y=a X^{b}
$$

Where $\mathrm{a}$ and $\mathrm{b}$ are constant parameters, $\mathrm{X}$ is an independent factor, and $Y$ is a dependent factor.

Equation 4;

$$
W=a L^{b}
$$

Where $W=$ Weight in $g, L=$ Length in $\mathrm{cm}$, $a=$ Intercept, $b=$ Slope

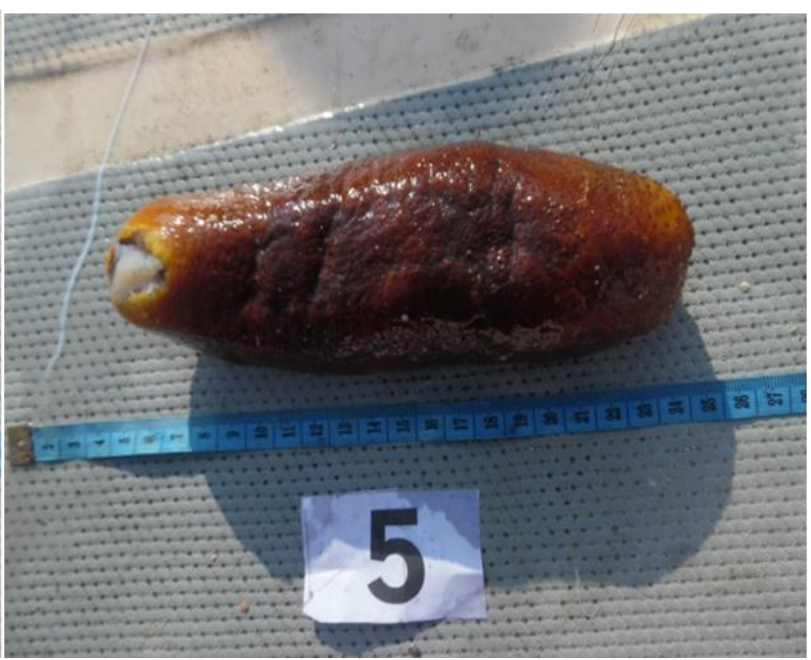


The parameters in equations 3 and 4 were calculated using the linear regression analysis (equation $5)$, which acts as an effective tool in allometric studies (Poot-Salazar et al., 2014).

Equation 5;

$$
\log W=\log a+b \log L
$$

Where $a$ is the intercept of the regression line (coefficient value related to body form) and $b$ is the regression coefficient (exponent representing the isometric growth pattern when $b$ is equal to the 3 ). Fulton's condition factor (K) was computed to identify the fitness of their environment for them as suggested by Pauly (1980) (equation 6).

Equation 6;

$$
K=100 \frac{W}{L^{3}}
$$

Where $\mathrm{K}=$ Condition factor, $\mathrm{W}=$ Weight in $\mathrm{g}$, $\mathrm{L}=$ Length in $\mathrm{cm}$

\section{Data Analysis}

Differences in the diversity/composition of sea cucumber species among localities were tested by oneway ANOVA considering "geographical location" as the fixed factor $(P<0.05)$. Variation of the length-weight measurements of sea cucumber species was tested by ANOVA using both "species" and "location" as fixed factors at $\mathrm{P}<0.05$ of the significance level. Post-Hoc Tukey HSD test was employed for pairwise comparisons of species diversity/composition and length-weight measurements between two specific factors $(P<0.05)$. The significance of the regression lines derived for length, and weight relationships was assessed using Fstatistic values. The student t-test was conducted to test the hypothesis of isometry $(b=3)$ in the length-weight relationships (Sokal \& Rohlf, 1981). Allometric growth occurred when either $b<3$ (negative) or $b>3$ (positive) in the regression line between length and weight parameters (equation 7).

\section{Equation 7;}

$$
t=\frac{b-3}{S b}
$$

Where $b=$ Regression coefficient of computed length, and weight relationship, $\mathrm{Sb}=$ Standard error of ' $b$ ', and $t=$ computed $t$ value

\section{Results}

\section{Species Diversity Assessment}

A total of 776 individuals belongs to four species [Holuthuria atra (Jaeger, 1833), Lolly Fish, Bohadschia marmorata (Jaeger, 1833), White Thread fish, Actinipyga miliaris, Deep Water Blackfish, and Thelenota ananas, Prickly Redfish] were identified in all study sites (Figure 3). Species richness varied in the range of 2-4 in

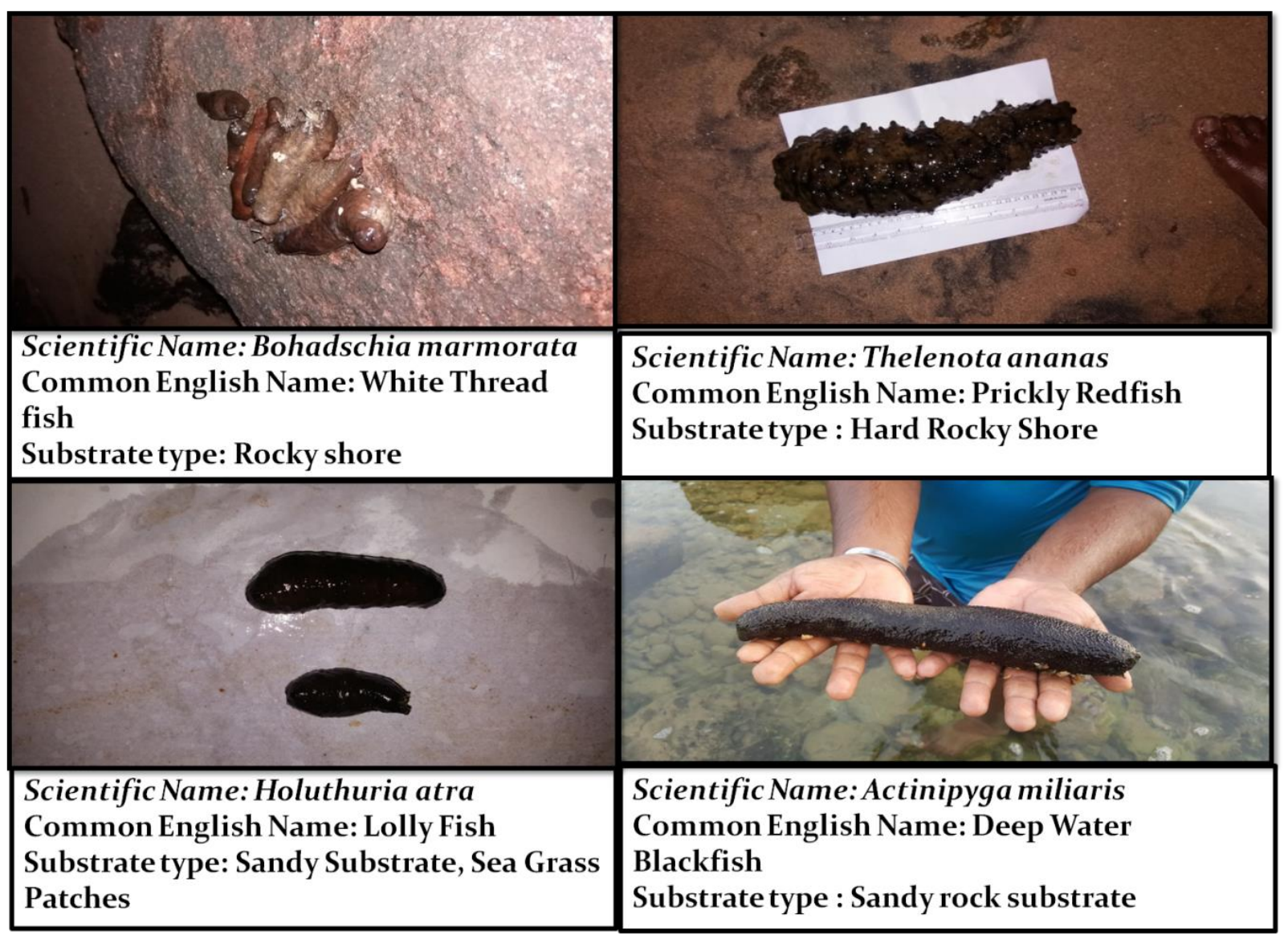

Figure 3. Sea cucumber species identified from the study sites. 


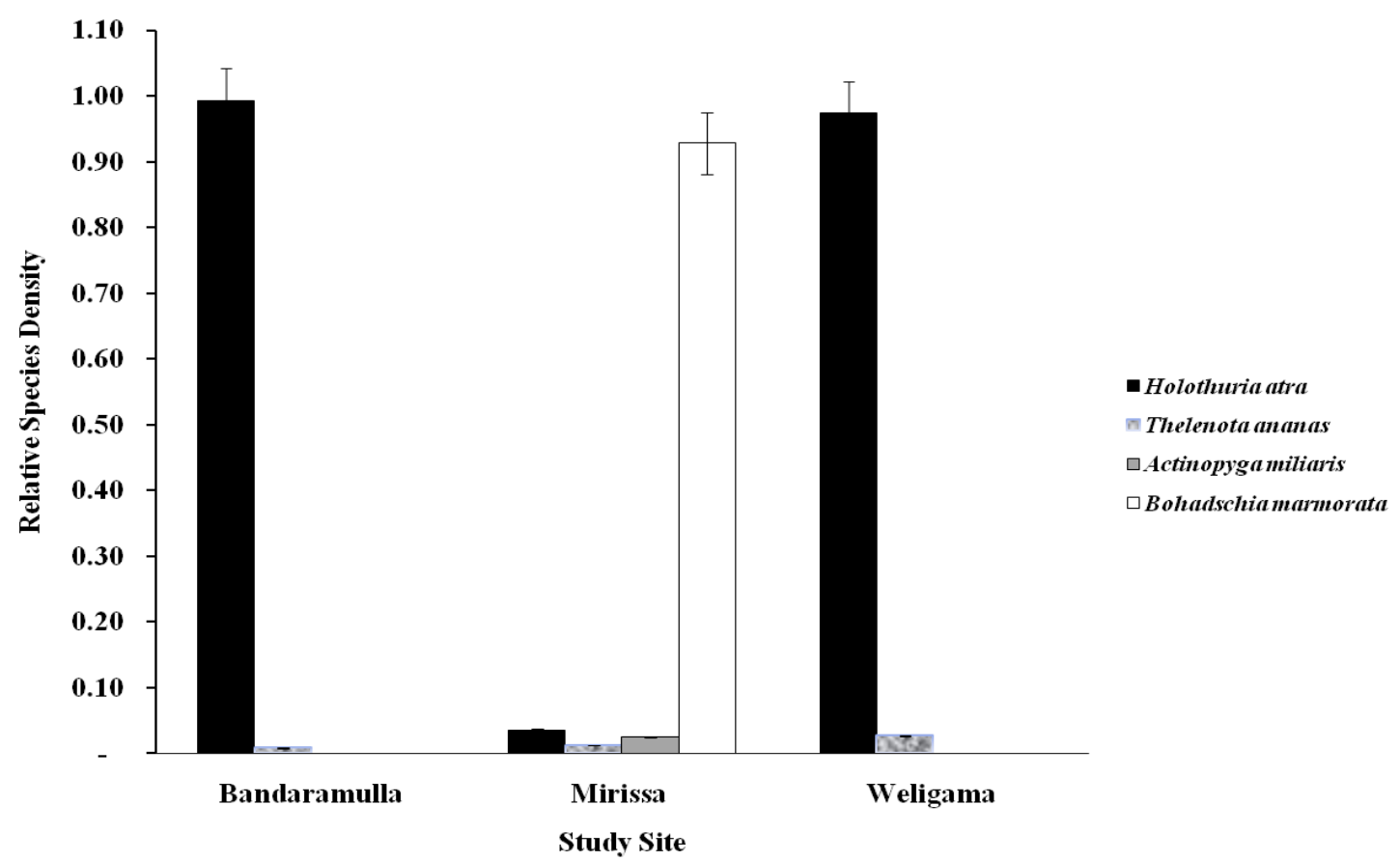

Figure 4. Relative species abundance of sea cucumbers in the study sites.

the study sites. The highest species richness (4) was recorded from the Mirissa site, while Bandaramulla and Weligama sites had similar species richness (2).

The highest relative sea cucumber species abundance was recorded for Holothuria atra (0.99 and 0.97 for Bandaramulla and Weligama sites, respectively) and Bohadschia marmorata (0.93 from Mirissa site), signifying optimum environmental conditions and appropriate factors for growth and survival in their respective ecosystems (Figure 4). However, comparatively lower individual number and relative species abundance was observed for Thelenota ananas and Actinopyga miliaris (Figure 4).

Composite Shannon-Weiner species diversity indices of sea cucumbers were 0.05, 0.12, and 0.33 in Bandaramulla, Weligama, and Mirissa sites, respectively. Further, species composition was significantly $(\mathrm{F}=2108.93, \mathrm{P}<0.05)$ different among the three study sites. However, the species composition of sea cucumbers between Bandaramulla and Weligama sites was statistically similar $(P>0.05)$ since the dominant species of the aforesaid two sites were Holothuria atra. Overall, the species diversity of sea cucumbers is comparatively lower in study sites of the southern coastal zone than the other studies reported in the literature.

\section{Assessment of Length-Weight (L-W) Relations and Condition Factor Aspects}

There were significant differences in length-weight measurements among sea cucumber species by ANOVA $(P<0.05, F=529.93$ (weight) and 599.49 (length)). Overall, the location had a significant effect on variations of length-weight parameters of sea cucumbers $(P<0.05)$. However, results of the Post-Hoc test recorded that both weight and length scores of Holothuria atra between Bandaramulla and Weligama sites were statistically similar at the level of $P>0.05$ (Table 1). Similarly, Bandaramulla and Mirissa sites had represented equal distribution patterns of lengthweight parameters for Thelenota ananas $(P>0.05$, Table 1). As per the results computed by length-weight measurements, the highest average weight $(1269.50 \pm 27.58 \mathrm{~g})$, and length $(36.00 \pm 1.41 \mathrm{~cm})$ were recorded for the Thelenota ananas collected from the Weligama region, while the lowest average weight $(10.11 \pm 5.57 \mathrm{~g})$ and length $(7.07 \pm 1.71 \mathrm{~cm})$ was reported by Bohadschia marmorata from Mirissa site (Table 1).

Table 2, and Figure 5 present the computed lengthweight relationships for each species in different localities. A linear regression model was not computed for the stocks of Thelenota ananas collected from Bandaramulla, and Weligama sites since a low number of individuals, and consequently, length-weight measurements were not sufficient for predicting respective relationships by the statistical software. Also, the derived regression model for Thelenota ananas collected from the Mirissa site revealed that the independent variable, length, was not significantly predicted by the dependent variable, weight (Table 2, $\mathrm{P}>0.05, \mathrm{~F}=2.59$ ).

The rest of the computed models for other species had a strong linear relationship between weight and length measurements, and the independent parameter significantly predicted the dependent variable by the derived models (Table 2, $\mathrm{F}=9.52-1794.16, \mathrm{P}<0.05$ ). Further, the independent variable (length) strongly contributed to more than $40 \%(0.4)$ of the explained variability of dependent factor (weight) in the derived regression models (Table 2 ). The " $b$ " values of standard length-weight regressions for all species in different 
Table 1. Average weight and length of collected holothurian species (values are in mean \pm STD)

\begin{tabular}{|c|c|c|c|c|c|c|c|}
\hline & \multicolumn{2}{|c|}{ Bandaramulla } & \multicolumn{2}{|c|}{ Mirissa } & \multicolumn{2}{|c|}{ Weligama } & \multirow{2}{*}{$\begin{array}{c}\text { Statistical } \\
\text { Similarity/ } \\
\text { Differences in } \\
\text { Weight (W)/ } \\
\text { Length (L) }\end{array}$} \\
\hline & Weight/g & Length/cm & Weight/g & Length/ cm & Weight/g & Length/cm & \\
\hline \multirow[t]{2}{*}{ Holothuria atra } & $289.63^{a} \pm$ & $17.63^{x_{ \pm}}$ & $248.65^{b} \pm$ & $15.95^{\mathrm{y}} \pm$ & $288.48^{a} \pm$ & $17.31^{x} \pm$ & $W^{*}$ \\
\hline & 21.89 & 4.55 & 10.70 & 0.66 & 10.48 & 3.95 & $L^{*}$ \\
\hline Thelenota & $1056.00^{d} \pm$ & $32.00^{s} \pm$ & $1072.86^{d} \pm$ & $33.14^{\mathrm{s}} \pm$ & $1269.50^{\mathrm{e}} \pm$ & $36.00^{r} \pm$ & $\mathrm{W}^{*}$ \\
\hline ananas & 11.51 & 3.10 & 74.99 & 1.46 & 27.58 & 1.41 & $L^{*}$ \\
\hline Actinopyga & $* *$ & $* *$ & $599.86 \pm$ & $30.21 \pm 4.12$ & $* *$ & $* *$ & N/A \\
\hline miliaris & & & 189.15 & & & & \\
\hline Bohadschia & $* *$ & $* *$ & $10.11 \pm$ & $7.07 \pm 1.71$ & $* *$ & $* *$ & N/A \\
\hline marmorata & & & 5.57 & & & & \\
\hline
\end{tabular}

Note:

** Species, which were not recorded from the respective sites.

* Overall, the source of variation of the length-weight parameters were statistically different at least between two geographical locations for the same species at $\mathrm{P}<0.05$ of significant level.

Based on the results of post-hoc test, length-weight scores that do not share the alphabet letters were significantly different between sampling locations at $\mathrm{P}<0.05$ of significant level.

N/A (Not Applicable): The statistical test was not computed by the software since the relevant species were recorded from only one study site.

Table 2. Summary of length-weight relationships computed for each sea cucumber species in different localities

\begin{tabular}{|c|c|c|c|}
\hline & \multicolumn{3}{|c|}{ Length-Weight Relationship } \\
\hline & Bandaramulla & Mirissa & Weligama \\
\hline \multirow[t]{6}{*}{ Holothuria atra } & Log Weight $=0.35+1.66$ Log & Log Weight $=0.46+1.59$ Log & Log Weight $=0.43+1.62$ Log \\
\hline & Length & Length & Length \\
\hline & $W=2.23 L^{1.66}$ & $W=2.89 L^{1.59}$ & $W=2.72^{1.62}$ \\
\hline & $R^{2}(r)=0.73$ & $R^{2}(r)=0.91$ & $R^{2}(r)=0.84$ \\
\hline & $F=314.30$ & $F=173.96$ & $F=375.32$ \\
\hline & $\mathrm{P}<0.05$ & $P<0.05$ & $P<0.05$ \\
\hline \multirow{6}{*}{$\begin{array}{l}\text { Thelenota } \\
\text { ananas }\end{array}$} & Note: The statistical software did & Log Weight $=1.70+0.87$ Log & Note: The statistical software \\
\hline & not compute linear regression due & Length* & did not compute linear \\
\hline & to fewer individuals with the & $W=50.23 L^{0.87}$ & regression due to fewer \\
\hline & smaller number of length-weight & $R^{2}(r)=0.34$ & individuals with a smaller \\
\hline & measurements of particular & $F=2.59$ & number of length-weight \\
\hline & species. & $p>0.05$ & $\begin{array}{l}\text { measurements of particular } \\
\text { species. }\end{array}$ \\
\hline \multirow[t]{5}{*}{$\begin{array}{l}\text { Actinopyga } \\
\text { miliaris }\end{array}$} & $\begin{array}{l}\text { Not recorded from the respective } \\
\text { site. }\end{array}$ & $\begin{array}{l}\text { Log Weight }=0.50+1.53 \text { Log } \\
\text { Length }\end{array}$ & $\begin{array}{l}\text { Not recorded from the } \\
\text { respective site. }\end{array}$ \\
\hline & & $W=3.18 L^{1.53}$ & \\
\hline & & $R^{2}(r)=0.44$ & \\
\hline & & $F=9.52$ & \\
\hline & & $\mathrm{P}<0.05$ & \\
\hline \multirow[t]{5}{*}{$\begin{array}{l}\text { Bohadschia } \\
\text { marmorata }\end{array}$} & $\begin{array}{l}\text { Not recorded from the } \\
\text { respective site. }\end{array}$ & $\begin{array}{l}\text { Log Weight }=-0.42+1.64 \text { Log } \\
\text { Length }\end{array}$ & $\begin{array}{l}\text { Not recorded from the } \\
\text { respective site. }\end{array}$ \\
\hline & & $W=0.38 L^{1.64}$ & \\
\hline & & $R^{2}(r)=0.77$ & \\
\hline & & $F=1794.16$ & \\
\hline & & $\mathrm{P}<0.05$ & \\
\hline
\end{tabular}

* Independent variable, the length was not significantly described the dependent variable, weight by the predicted regression model ( $P>0.05)$.

Table 3. Fulton's coefficient of condition factors (K) for the recorded sea cucumber species in the southern coast of Sri Lanka

\begin{tabular}{lllll}
\hline & \multicolumn{4}{c}{ Mean Fulton's condition factor (K) } \\
\cline { 2 - 5 } & Holothuria atra & Thelenota ananas & Actinopyga miliaris & Bohadschia marmorata \\
\hline Bandaramulla & $6.48 \pm 1.17$ & $3.22 \pm 0.09$ & $*$ & $*$ \\
Mirissa & $7.84 \pm 1.58$ & $2.97 \pm 0.36$ & $2.23 \pm 0.69$ & $3.05 \pm 2.08$ \\
Weligama & $5.94 \pm 2.12$ & $2.73 \pm 0.26$ & $*$ & $*$ \\
\hline
\end{tabular}

* Particular species was not recorded from the respective site. 


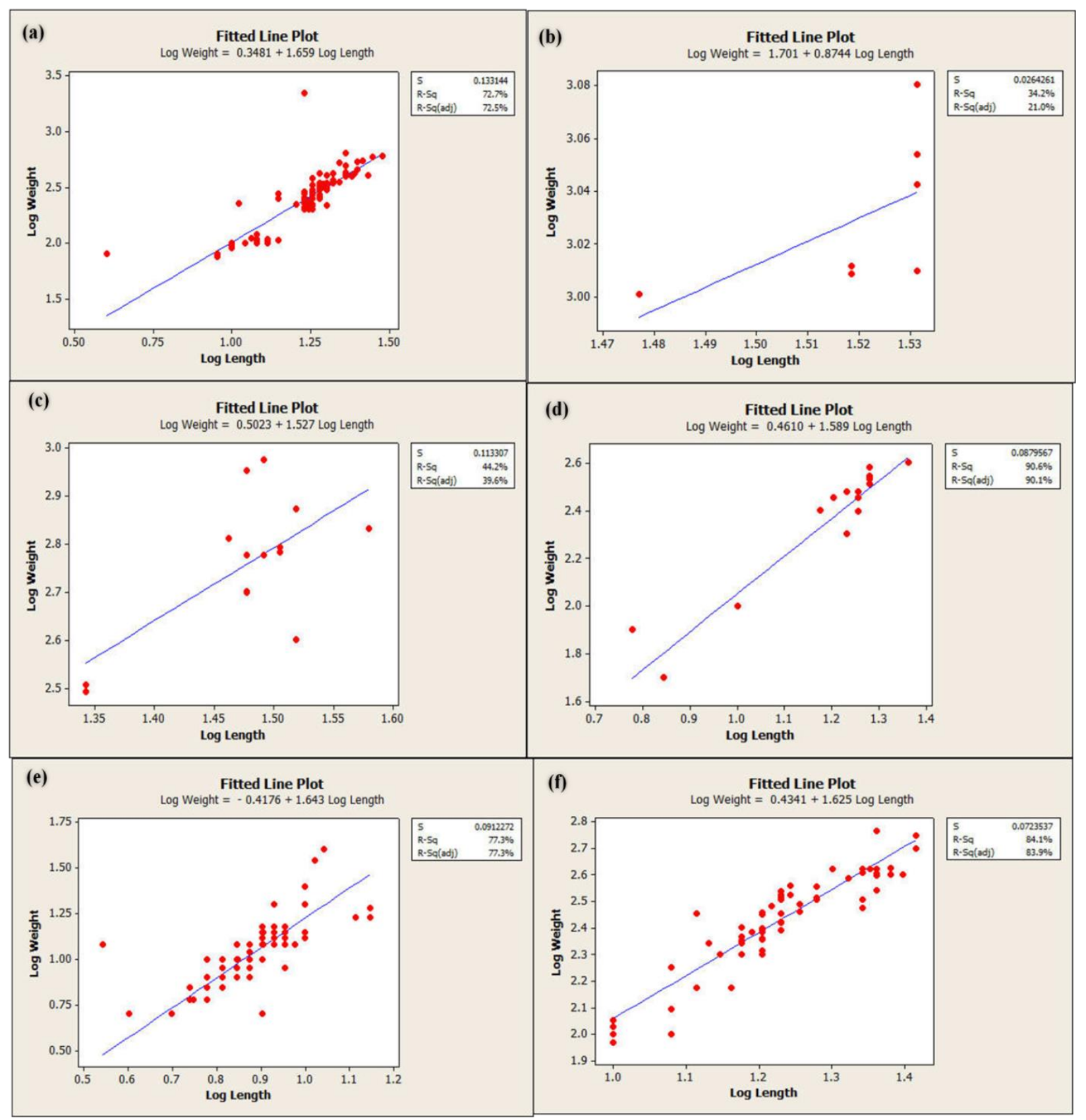

Figure 5. Derived fitted line plot for length-weight relationships of different sea cucumber species in study sites of southern coast, Sri Lanka (a) Holothuria atra in Bandaramulla (b) Thelenota ananas in Mirissa (c) Actinopyga miliaris in Mirissa (d) Holothuria atra in Mirissa (e) Bohadschia marmorata in Mirissa (f) Holothuria atra in Weligama

sites were lower at the range between 1.53-1.66 (Table 3 and Figure 5). Moreover, results of Student " $\mathrm{t}$ " tests revealed that all the derived " $b$ " values were significantly different compared to the test value of " 3 " $(b \neq 3, P<0.05)$.

The average Fulton's condition factors (K) calculated for different sea cucumber species in three localities are presented in Table 3. Based on the present results, the average condition factors in various sites range at (5.94 - 7.84) and (2.73 - 3.22) for Holothuria atra and Thelenota ananas, respectively, while 2.23 and 3.05 were recorded for Actinopyga miliaris and Bohadschia marmorata (Table 3). The highest condition factor was recorded for one of the dominant species,
Holothuria atra, from all the sites by indicating favorable environmental conditions and physical healthiness of individual organisms (Table 3).

\section{Discussion}

There were seven sea cucumber species belonged to two families in the coastal regions of Mullaitivu and Point Pedro along the northeast region of Sri Lanka (Veronika et al., 2016; Veronika et al., 2017). However, the sea cucumber species richness in our study sites is lower in the southern coastal zone than that of former sites. Fourteen sea cucumber species of Actinopyga have been recorded from the Sabah region (Semporna 
in the southern part and Kota Tuaran and Kinabalu in the northern part), Malaysia, from August 2004 to October 2007 (Kamarudin et al., 2009). Variations in the abundance, species richness, species diversity, and their distribution are a function of hydrodynamics and substrate characteristics (e.g., substrates with organic sediment accumulation) (Barkai, 1991; Kerr et al., 1993; Mosher, 1980). Therefore, these reasons may be the possible causes for the observed variation in the abundance of holothurians in the northern and southern coasts of Sri Lanka. Among seven sea cucumber species reported in the northeast region of Sri Lanka, Holothuria atra, Bohadschia marmorata, Stichopus naso (Samper, 1868), and Holothuria spinifera (Theel, 1886) are identified as commercially important sea cucumber species (Veronika et al., 2018). Toral-Granda et al. (2008) reported that $B$. marmorata, A. miliaris, $H$. atra, and Thelenota ananas are widely used to produce expensive beche-de-mer or beches-de-mer (processed product/s of sea cucumber flesh in the boiled, dried, and smoked form) in the western central Pacific region. These four species have been recorded in the current study, indicating appropriate habitat suitability on the southern coast to adopt sustainable management strategies for further development and conservation approaches.

Similar to the present findings, sea cucumber species belonging to order Aspidochirotida and genus Holothuria is noted as the primary taxonomic groups in Malaysia (Kamarudin et al., 2009). However, FuenteBetancourt et al. (2001) revealed that the density of $H$. floridana is lower compared to the other commercially important sea cucumber species found in fishing grounds of Banco Chinchorro, Quintana Roo, Mexico. This finding is quite contradictory to our study results. The current study identified that two study sites (Bandaramulla and Weligama) have the highest abundance of $H$. atra and has a smaller number of other sea cucumber species by representing the dominancy of $H$. atra in their respective habitats. Lampe-Ramdoo et al. (2014) has further confirmed these results. H. atra has a possibility in preventing the recruitment of other sea cucumber species successfully in the same ecosystem. Further, $H$. atra's reproduction rate is comparatively higher than that of other species, and this group has the potential to adopt different habitats while tolerating the harsh environmental conditions. Accordingly, $\mathrm{H}$. atra can establish in the new ecological niches when the stock of a particular sea cucumber species is vulnerable to depletion or dramatically reduced by overexploitation. As a result, this species, with a diverse range of possible habitats or niches, can settle in new potential habitats or ecosystems immediately due to less inter-specific competition (Lampe-Ramdoo et al., 2014). The above factors would significantly contribute to the dominance of $H$. atra with higher densities in their respective environment, which is valuable baseline information regarding the sea cucumber species diversity in the southern coast of Sri Lanka.
The current study identified a relatively lower species diversity in the study sites of Sri Lanka. However, Kamarudin et al. (2009) revealed that the sea cucumber species diversity level in Malaysia's east coast region is higher than that of the west coast region, while Baine and Forbes (1998) had recorded higher sea cucumber diversity with 19 species in Tioman Island. Anthropogenic, biogeographical, and environmental factors affect species diversity in an ecosystem. The rich sea cucumber diversity in Tioman Island was mainly due to the zero effect from freshwater outputs (e.g., runoff from the rivers) along the coastal zone, consequently developing diverse, healthy coral ecosystems (Baine \& Forbes, 1998). Kamarudin et al. (2009) also confirmed that extensive distribution of coral reefs and lower anthropogenic effects, including minor marine pollution, significantly impact the high diversity of sea cucumber species in respective ecosystems. Lower sea cucumber species diversity was also recorded because of anthropogenic influence from Peninsular Malaysia, especially in Langkawi Island (Kamarudin et al., 2009). However, the current study strongly recommends a long-term, comprehensive scientific investigation on sea cucumber diversity while analyzing anthropogenic factors and biogeographical characteristics in the entire coastal zone of the southern province in Sri Lanka to better understand the species diversity level, occurrence, and distribution of sea cucumbers in specific habitats. In particular, the southern coast of Sri Lanka is a highly popular recreational destination for both local and international tourists, which, in turn, has an immense potential to disturb these ecosystems.

Length and weight parameters could act as distinguishable morphometric characters to maintain the identity of a particular sea cucumber species. However, weight measurement is identified as a highly reliable parameter of sea cucumber population dynamics, whereas the length is subjected to considerable changes causing severe difficulties in recognizing the complete relaxation state of the sea cucumber body (Conand, 1981; Tuwo \& Conand, 1992; Zakanidis et al., 2010). The past literature works have recorded the length-weight measurements of the sea cucumbers from different geographical locations. Compared to $B$. marmorata collected in the northern region of Sri Lanka (W=516g, $L=22 \mathrm{~cm})$, the same species on the southern coast is smaller in size. In comparison, the average length and weight of $H$. atra were $23 \mathrm{~cm}$, and $245 \mathrm{~g}$, respectively, sampled from the same site (Veronika et al., 2018). For the same species collected from the east coast of Sri Lanka, the average length and weight were reported as $23.3 \pm 1.3 \mathrm{~cm}$ and $111 \pm 6 \mathrm{~g}$, respectively (Dissanayaka \& Stefansson, 2010). The former weight was significantly lower than that of other reports and the present finding. On the other hand, both H. atra and B. marmorata exhibited comparatively longer body length and higher body weight for the samples collected from the northwest coastal region of Sri Lanka (Dissanayaka \& Wijeyaratne, 2007). 
According to Gonzalez-Wanguemert et al. (2014), the average lengths of $H$. polii, and $H$. tubulosa were $10.51 \mathrm{~cm}$, and $16.40 \mathrm{~cm}$, while the average weights of the aforesaid two species were $37.59 \mathrm{~g}$, and $88.78 \mathrm{~g}$, respectively. These records are relatively lower than the average length-weight measurements of Holothuria atra in the current study (Table 1). The morphometric characteristics of commercially important holothurian species in the western central Pacific region were further studied (SPC, 2003), which recorded comparatively lower respective measurements $(25 \mathrm{~cm}$, and $400 \mathrm{~g}$ ) for $A$. miliaris from the aforesaid Pacific region. Further, the average length-weight measurements of Holothuria atra $(20 \mathrm{~cm}$, and $200 \mathrm{~g})$, and Thelenota ananas $(45 \mathrm{~cm}$, and $2500 \mathrm{~g})$ collected from the western central Pacific region (SPC, 2003) were found to be significantly different compared to the results of the current study.

Length-weight measurements are considered as growth parameters of a particular species. Changes in the above parameters of the same species at different geographical locations indicate the overall environmental quality in their respective habitat/s, including food abundance, growth rate, and biological characters of the species, and differences in applied fishing efforts (Gonzalez-Wangüemert et al., 2014). Genetic effects, in addition to the environmental factors, are also responsible for the inter-specific variations of respective growth parameters of aquatic organisms.

All the computed " $b$ " values for each sea cucumber species were statistically different compared to the reference test value of “ 3 " $(b \neq 3)$. When $b=3$, isometric growth where increment rate of length is proportionate or equals to increase the weight of relevant species. If the " $b$ " value is higher than " 3 ", positive allometric growth is indicated with a faster weight increment rate than the length increment. If the regression coefficient is lower than value " 3 ", negative allometric growth is recorded by the respective species. Accordingly, the current study identified that all the derived " $b$ " values in the models were less than " 3 " by exhibiting a negative allometric growth pattern for all sea cucumber species (Froese, 2006; Pauly, 1980). This finding signifies the more elongated body of sea cucumbers as a distinctive morphological character by emphasizing that the rate of length increment is higher than that of the weight increase of sea cucumbers in the study sites (Veronika et al., 2018). Further, this growth pattern emphasizes that all the sea cucumbers species are likely to be gaining less weight in all the sampling locations.

The current result is further agreed with the former study findings conducted in the northeast coastal region of Sri Lanka, as H. spinifera (1.89), B. marmorata (1.11), $S$. naso (1.02), and $H$. atra (1.22) produced lower $b$ values. Thus, elongated body shape is a typical morphological character of the most abundant sea cucumber species identified from both southern and north-eastern regions of Sri Lanka. Also, H. spinifera, $B$. marmorata, and $H$. atra collected from the Gulf of Mannar, India, have recorded negative allometric growth patterns $(b<3)$, confirming current findings (Venkataraman, 2007). In the north-western coastal zone of Yucatan state, Mexico, the overall growth pattern of Isostichopus badionotus was found to be negative allometric $(b<3)$ with seasonal variations of the growth rate of this species. A slow or zero growth rate was identified from October to November, with severe/harsh weather situations from the northwestern coastal shore of Yucatan state, Mexico (PootSalazar et al., 2014).

Extremely lower " $b$ " values of particular species were found to be associated with their feeding mechanisms and adverse climatic/seasonal effects (Ahmed et al., 2018; Kamaruzzaman et al., 2010). Some sea cucumber species are deposit-feeders, and they usually ingest the sediments rich in organic matter in their living environment (Slater \& Carton, 2009). The qualitative, and quantitative characters of coastal, and marine sediments are modified due to the prevailing post-monsoonal event (e.g., increasing grain size of sediments) and consequently affected the organic matter content in the sediment. Accordingly, changes in sediment characteristics negatively impact on food availability of sea cucumbers and therefore influence their growth in terms of negative allometric growth (Ahmed et al., 2018; Kamaruzzaman et al., 2010).

When the location was separately considered, regression model of length-weight relationship derived for Isostichopus badionotus showed an isometric growth pattern ("b" value closer to " 3 ") at Progreso in the northwestern coast of Yucatan state, Mexico (Poot-Salazar et al., 2014). However, many works of literature had recorded the allometric growth pattern for the most of common holothurian species found in many marine ecosystems worldwide (Ahmed et al., 2018; Aydin, 2020; Bulteel et al., 1992; Gonzalez-Wanguemert et al., 2014; Herrero-Perezrul \& Reyes-Bonilla, 2008; Soedarto \& Tembalang, 2019; Ramon et al., 2010).

During allometric growth patterns, either the rate of length increment or weight gain is relatively faster for a particular species (positive or negative allometric growth). Both these growth patterns seem to be advantageous by declining the mortality rate of sea cucumber species through predatory activities in their respective habitats (Coulon \& Jangoux, 1993; VergaraChen et al., 2010; Zakanidis et al., 2010). However, the regression models of length-weight relationships and derived " $b$ " values within the same species but different stocks (intra-specific) depends on several factors, such as climatic condition (pre-monsoon, monsoon, and postmonsoon), the healthiness of individuals, fishing season, and geographical location, while respective interspecific relationships change with the body shape, which is unique to certain species, apart from above factors (Ahmed et al., 2018; Herrero-Perezrul \& Reyes-Bonilla, 2008; Medina-Reyha, 2001; Prasad, 2001). These biometric relationships are essential in estimating 
different factors and indices such as growth parameters which act as the direct indicators in the population dynamics of aquatic organisms.

The condition factor acts as the indicator reflecting the living environment condition and the well-being of the individual organism (Pauly, 1980). Thus, K is commonly used to identify the quality of habitats where sea cucumbers live and the healthiness of organisms in most population dynamics, fisheries management, and fish biology studies (Nash et al., 2006). Overall, the physical state of all the sea cucumber species found to be optimum in all three study sites when considering the respective values of condition factor, which was greater than "01". Another past study had recorded that all identified sea cucumber species were in a good physical state by recording the mean condition factors (K) for $\mathrm{H}$. spinifera, $H$. atra, $S$. naso, and $B$. marmorata as (3.89 \pm 1.03$),(2.69 \pm 1.34),(3.56 \pm 1.73)$ and $(4.12 \pm 2.21)$, respectively, in the north-eastern coastal region of Sri Lanka (Veronika et al., 2018). The average condition factor values of $H$. tubulosa, $H$. polii, $H$. mammata, and $H$. sanctori were at the range of (1.73-4.45) at the Aegean Sea in territorial waters of Turkey where sea cucumber harvesting is legally practiced, and the stock density of sea cucumbers is at a higher level (Aydın, 2020). These past findings are compatible with the present results except the condition factor values recorded for Holothuria atra from study sites (Table 3). Relatively lower Fulton's condition factor values were reported for Holothuria atra collected from different sites (Menjangan Kecil: 1.91, Menjangan Besar: 1.89, Wisma Apung: 1.37, Alang-alang: 1.34) in Karimunjawa National Marine Park region, Indonesia (Soedarto \& Tembalang, 2019). Since K>1 (1.34-1.91), adequate food surplus for sea cucumbers in the respective waters of Indonesia has been revealed by the aforesaid study.

Condition factor (K) for Juvenile stages of Holothuria scabra had a significant negative linear relationship with Body Length (BL), Body Volume (BV), and Body Weight (BW) (Watanabe et al., 2011). Compared to the other taxonomic groups having exoskeletons, the " $\mathrm{K}$ " factor is not an effective index in assessing the nutritional state of $H$. scabra due to the associated changes in their body weight and size (Watanabe et al., 2011). Based on the condition factor, this study reveals the optimum environment quality for aforesaid sea cucumber species in study sites of the southern coastal zone, Sri Lanka. Moreover, the authors recommend conducting a comprehensive feasibility study on other physicochemical water quality parameters, environmental factors, and appropriate survival conditions of sea cucumbers in the selected sites for further confirmation.

The length-weight relationships and Fulton's condition factor values would be highly useful in implementing sustainable sea cucumber fisheries management programs in respective coastal and marine regions (Froese, 2006). Accordingly, scientific studies are recorded on sea cucumber fishery, management practices, and their population dynamics aspects as an approach toward the sustainability of the identified stocks. Anderson et al. (2011), Purcell et al. (2012a, b), and Toral-Granda (2008) have studied the current status and adopted management measures for the sea cucumber fishery in five regions across the world. For sustainability and conservation of the sea cucumber populations along the Aegean Sea, Turkey, it is recommended to (i) maintain the fishery efforts of $H$. polii, and $H$. tubulosa, (ii) establish the protected areas by prohibiting the harvesting of sea cucumbers for maintaining healthy populations through providing conditions for the new recruitment along nearby regions of Aegean sea, (iii) conduct scientific studies on assessing the harvested sea cucumber stocks and calculate the recovery time of sea cucumber populations in the North Turkish coastal region, and (iv) identify and re-establish the species-specific closed fishery season by considering the reproductive cycle of each sea cucumber species (Gonzalez-Wanguemert et al., 2014). Isostichopus badionotus stock was identified along the northern Yucatan Peninsula continental shelf during the last decade. This stock gained a high demand among sea cucumber harvesters and traders, revealing a new array of expansion and development of sea cucumber fishery (Alfonso et al., 2004). Since $I$. badionotus has played a significant role in sea cucumber fishery in Cuba, Venezuela, and Panama along the western Atlantic region, the distribution, abundance, and biomass assessment of this species have been scientifically investigated for sustainable fishery management practices (Alfonso et al., 2004; Selenka, 1867).

The basic need for initiating mariculture of sea cumber is selecting a suitable site by concerning the selected species' requirements. Habitat characteristics are constantly changing in a dynamic coastal and marine environment; therefore, the use of temporal condition factor based on the species' length-weight data is one of the fundamental reliable methods to select an appropriate site. This is the first study focused on lengthweight measurements and condition factors of sea cucumbers species in the Weligama-MirissaBandaramulla area as a subsite of the southern coast of Sri Lanka. Although sea cucumber farming has been tested in some regions (e.g., north-western, and northern provinces), the aforesaid sites in the southern province have not been considered for exploring the cultural potential of sea cucumbers in Sri Lanka. Therefore, we recommend initiating feasible scientific studies/projects to identify the potential/s in sea cucumbers' site-specific mariculture farming practices in this area. Also, regular monitoring and surveys on sea cucumber abundance and distribution patterns help protect the existing sea cucumber diversity in these subsites. 


\section{Conclusion}

This study investigated the species diversity, length-weight relationships, and condition factors of sea cucumber species in a selected region of the southern coastal zone of Sri Lanka. Four sea cucumber species, i.e., Holothuria atra, Bohadschia marmorata, Actinipyga miliaris, and Thelenota ananas, were recorded from the study sites. The species diversity of the sea cucumbers in the Mirissa site was higher than that of Bandaramulla and Weligama. This finding emphasizes that habitat characteristics were instrumental in determining the sea cucumber diversity in a respective ecosystem. Three of the identified sea cucumber species exhibited a strong regression model of length-weight relationship and negative allometric growth patterns. Study sites in the southern coastal region endow with a healthy living environment for optimum growth of sea cucumbers. Thus, this study further recommends a thorough scientific investigation on confirming the habitat suitability and identifying the mariculture potential of the aforesaid species in the study sites of southern Sri Lanka. Our findings would probably serve as baseline information that benefits managing and conserving sea cucumber resources in Sri Lankan coastal waters.

\section{Ethical Statement}

Not applicable.

\section{Funding Information}

Not applicable.

\section{Author Contribution}

Kumara T.G.L.: Investigation, Data curation, Methodology, Formal analysis. Thushari G.G.N.: Methodology, Formal analysis, Supervision, Conceptualization, Validation, Writing - Original draft, Review \& Editing. Atapaththu K.S.S.: Investigation, Methodology, Formal analysis, Supervision, Validation, Review \& Editing. Kumara H.K.R.S.: Investigation, Supervision, Review \& Editing. Senevirathna J.D.M.: Methodology, Formal analysis, Visualization, Writing, Review \& Editing.

\section{Conflict of Interest}

All authors do not have any conflict of interest.

\section{Acknowledgements}

We, authors convey our sincere gratitude to the anonymous reviewers for their contribution to improve the quality and readability of the manuscript.

\section{References}

Ahmed, Q., Poot-Salazar, A., Ali, Q.M., \& Bat, L. (2018). Seasonal Variation in the Length-Weight Relationships and Condition Factor of Four Commercially Important Sea Cucumbers Species from Karachi Coast-Northern Arabian Sea. Natural and Engineering Sciences, 2018, 3(3): 265-281. doi: https://doi.org/10.28978/nesciences.468667

Alfonso, I., Frías, M.P., Aleaga, L., \& Alonso, C.R. (2004). Current status of the sea cucumber fishery in the south eastern region of Cuba. In: Advances in Sea Cucumber Aquaculture and Management. http://www.fao.org/3/y5501e0k.htm

Anderson, S.C., Flemming, J.M., Watson, R., \& Lotze, H.L. (2011). Serial exploitation of global sea cucumber fisheries. Fish and Fisheries 2011, 12, 317-339. https://doi.org/10.1111/j.1467-2979.2010.00397.x

Aydın, M. (2020). Length-weight relationships and condition factor of four different sea cucumber species in the Aegean Sea. Journal of Anatolian Environmental and Animal Sciences, 5 (1), 80-85. https://doi.org/10.35229/jaes.677940

Baine, M. \& Forbes, B. (1998). The taxonomy and exploitation of sea cucumbers in Malaysia. SPC Beche-de-mer Information Bulletin 10, 2-7.

Barkai, A. (1991). The effect of water movement on the distribution and interaction of three holothurians species on the South African West Coast. Journal of Experimental Marine Biology and Ecology, 153, 241-254. https://doi.org/10.1016/0022-0981(91)90228-O

Bulteel, P., Jangoux, M., \& Coulon, P. (1992). Biometry, bathymetric distribution, and reproductive cycle of the holothuroid Holothuria tubulosa (Echinodermata) in Mediterranean seagrass beds. Marine Ecology, 13(1), 5362. https://doi.org/10.1111/j.1439-0485.1992.tb00339.x

Clark, A.M., \& Rowe, F.E.W. (1971). Monograph of shallowwater Indo-West Pacific echinoderms. Trustees of the British Museum, British Museum (Natural History), London.

Conand, C. (1981). Sexual cycle of three commercially important holothurian species (Echinodermata) from the lagoon of New Caledonia. Bulletin of Marine Science, 31(3): 523-543

Conand, C. \& Byrne, M. (1993). A review of recent developments in the world sea cucumber fisheries. Marine Fisheries Review, 55(4), pp. 1-13. http://spo.nmfs.noaa.gov/mfr554/mfr5541.pdf

Conand, C. (2000). Sea cucumber retail market in Singapore. SPC Beche-de-mer Information Bulletin 14, 12-13.

Conand, C. (2004). Present status of world sea cucumber resources and utilization: an international overview. In Advances in Sea Cucumber Aquaculture and Management, FAO Fisheries Technical Paper, No. 463. Lovatelli, A., Conand, C., Purcell, S., Uthicke, S., Hamel, J. F., Mercier, A., Eds.; FAO: Rome; pp. 13-24.

Coulon, P. \& Jangoux, M. (1993). Feeding rate and sediment reworking by the holothuroid Holothuria tubulosa (Echinodermata) in a Mediterranean seagrass bed off Ischia Island, Italy. Marine Ecology Progress Series. 92, 201-204. doi:10.3354/MEPS092201

Dissanayake, D.C.T., \& Wijeyaratne, M.J.S. (2007). Studies on the sea cucumber fishery in the North Western coastal 
region of Sri Lanka. Sri Lanka Journal of Aquatic Sciences. 12, 19-38. doi: 10.4038/sljas.v12i0.2212

Dissanayake, D., Athukorala, S. \& Amarasiri, C. (2010). Present status of the sea cucumber fishery in Sri Lanka. SPC Beche-de-mer Information Bulletin 30, 14-20.

Dissanayake, D.C.T., \& Stefansson, G. (2010). Abundance and distribution of commercial sea cucumber species in the coastal waters of Sri Lanka. Aquatic Living Resources, 23(3), 303 - 313. https://doi.org/10.1051/alr/2010031

Food and Agriculture Organization of the United Nations (FAO), (2011). Code of Conduct for Responsible Fisheries Special Edition. 91p, Rome.

Francour, P. (1997). Predation on holothurians: a literature review. Invertebrate Biology, 116(1), 52-60. https://doi.org/10.2307/3226924

Froese, R. (2006). Cube law, condition factor and weightlength relationships: History, meta-analysis and recommendations. 22, 241-253. https://doi.org/10.1111/j.1439-0426.2006.00805.x

Fuente-Betancourt, M.G., Jesús-Navarrete, A., Sosa-Cordero, E., \& Herrero-Perezrul, M.D. (2001). Assessment of the sea cucumber (Echinodermata: Holothuroidea) as potential fishery resource in Banco chinchorro, Quintana Roo, Mexico. Bulletin of Marine Science, 68, 59-67.

Duarte, L., García, C., Sandoval, N., Schiller, D.V., Melo, G., \& Navajas, P. (1999). Length-weight relationships of demersal fishes from the Gulf of Salamanca, Colombia.

González-Wangüemert, M., Aydin, M., \& Conand, C. (2014). Assessment of sea cucumber populations from the Aegean Sea (Turkey): First insights to sustainable management of new fisheries. Ocean \& Coastal Management, 92, 87-94. http://dx.doi.org/10.1016/j.ocecoaman.2014.02.014.

Haimovici, M., \& Velasco, G. (2000). Length-weight relationship of marine fishes from southern Brazil.

Hendler, G., John, E., Pawson, D., \& Kier, P. (1995). Sea Stars, Sea Urchins, and Allies: Echinoderms of Florida and the Caribbean.

Herrero-Pérezrul, M.D., \& Reyes-Bonilla, H. (2008). WeightLength relationship and relative condition of the holothurian Isostichopus fuscus at Espíritu Santo Island, Gulf of California, México. Revista De Biologia Tropical, 56, 273-280. doi:10.15517/RBT.V56I3.27143

Kamarudin, K., Rehan, A.M., Lukman, A., Ahmad, H.F., Anua, M.H., Nordin, N., Hashim, R., Hussin, R., \& Usup, G. (2009). Coral Reef Sea Cucumbers in Malaysia. Malaysian Journal of Science, 28, 171-186. https://doi.org/10.22452/mjs.vol28no2.6.

Kamaruzzaman, B., Waznah, A.S., Shahbudin, S., Jalal, K.A., \& Ong, M.C. (2010). The temporal variation of organic carbon during the pre-monsoon and post-monsoon seasons in Pahang River-estuary, Pahang, Malaysia. Oriental Journal of Chemistry, 26, 1309-1313.

Kerr, A., Stoffel, E., \& Yoon, R. (1993). Abundance distribution of holothuroids (Echinodermata: holothuroidea) on a windward and leeward fringing coral reef, Guam, Mariana Islands. Bulletin of Marine Science, 52, 780-791.

Lampe-Ramdoo, K., Pillay, R.M., \& Conand, C. (2014). An assessment of holothurian diversity, abundance and distribution in the shallow lagoons of Mauritius.

Cren, E.L. (1951). THE LENGTH-WEIGHT RELATIONSHIP AND SEASONAL CYCLE IN GONAD WEIGHT AND CONDITION IN THE PERCH (PERCA FL UVIA TILIS). Journal of Animal Ecology, 20, 201. doi: 10.2307/1540
MacTavish, T., Stenton-Dozey, J., Vopel, K., \& Savage, C. (2012). Deposit-Feeding Sea Cucumbers Enhance Mineralization and Nutrient Cycling in OrganicallyEnriched Coastal Sediments. PLOS ONE, 7. doi: 10.1371/journal.pone.0050031

Magurran, A. (2003). Measuring Biological Diversity.

Medina-Reyna, C.E. (2001). Growth and emigration of white shimp, Litopenaeus vannamei, in the Mar Muerto Lagoon, Southern Mexico.

Morris, E.K., Caruso, T., Buscot, F., Fischer, M., Hancock, C., Maier, T.S., Meiners, T., Müller, C., Obermaier, E., Prati, D., Socher, S.A., Sonnemann, I., Wäschke, N., Wubet, T., Wurst, S., \& Rillig, M. (2014). Choosing and using diversity indices: insights for ecological applications from the German Biodiversity Exploratories. Ecology and Evolution, 4, 3514 - 3524

Mosher C (1980). Distribution of Holothuria arenicola semper in the Bahamas with observations on habitat, behavior, and feeding activity (Echinodermata: Holothuroidea). Bulletin of Marine Science. 30: 1-12.

Nash, R., Valencia, A., \& Geffen, A. (2006). The origin of fulton's condition factor: Setting the record straight. Fisheries, 31, 236-238.

Pangestuti, R., \& Arifin, Z. (2018). Medicinal and health benefit effects of functional sea cucumbers. Journal of Traditional and Complementary Medicine, 8, 341 - 351. doi: 10.1016/j.jtcme.2017.06.007

Pauly, D. (1980). A selection of simple methods for the assessment of tropical fish stocks.

Poot-Salazar, A., Hernández-Flores, Á., \& Ardisson, P. (2014). Use of the SLW index to calculate growth function in the sea cucumber Isostichopus badionotus. Scientific Reports, 4. doi: 10.1038/srep05151.

Prasad, G. (2001). Length-weight relationships of Penaeus monodon reared in semi-intensive culture systems of Kerala, India.

Purcell, S., Lovatelli, A., Vasconcellos, M., \& Yi-min, Y. (2010). Managing sea cucumber fisheries with an ecosystem approach.

Purcell, S., Mercier, A., Conand, C., Hamel, J., Toral-Granda, M.V., Lovatelli, A., \& Uthicke, S. (2013). Sea cucumber fisheries: global analysis of stocks, management measures and drivers of overfishing. Fish and Fisheries, 14, 34-59. http://dx.doi.org/10.1111/j.1467-2979.2011.00443.x.

Purcell, S.W., Samyn, Y., \& Conand, C. (2012). Commercially Important Sea Cucumbers of the World, FAO Species Catalogue for Fishery Purposes.

Ramón, M., Lleonart, J., \& Massuti, E. (2010). Royal cucumber (Stichopus regalis) in the northwestern Mediterranean: Distribution pattern and fishery. Fisheries Research, 105, 21-27. https://doi.org/10.1016/j.fishres.2010.02.006

Selenka, E. (1867). Anatomie und, B-g. Systematik der Holothurien. Zeitschrift für wissenschaftliche Zoologie. 17, 291-374.

Slater, M., \& Carton, A.G. (2009). Effect of sea cucumber (Australostichopus mollis) grazing on coastal sediments impacted by mussel farm deposition. Marine Pollution Bulletin, 58 8, 1123-1129. doi:10.1016/j.marpolbul.2009.04.008

Soedarto, J.L., \& Tembalang, S.H. (2019). Length-Weight Relationship and Condition Factor of Black Sea Cucumber (Holothuria atra) in Karimunjawa National Marine Park Area. MAQUARES, 8(4): 327-336. 
Rr, S., \& Fj, R. (1981). Biometry: the principles and practice of statistics in biological research $2^{\text {nd }}$ edition.

SPC (Secretariat of the Pacific Community), (2003). Beche-demer Information Bulletin, 18. 97715 Saint-Denis Cedex, La Réunion, France.

Toral-Granda, V., Consultant, F., \& Ayora, P. (2008). Population status, fisheries and trade of sea cucumbers in Latin America and the Caribbean.

Toral-Granda, V., Lovatelli, A., Vasconcellos, M., Conand, C., Hamel, J., Mercier, A., Purcell, S., \& Uthicke, S. (2008). Sea cucumbers. A global review of fisheries and trade.

Tuwo, A., \& Conand, C. (1992). Reproductive biology of the holothurian Holothuria forskali (Echinodermata). Journal of the Marine Biological Association of the United Kingdom, 72, 745-758. doi: $10.1017 /$ S0025315400060021

Uthicke, S., Welch, D., \& Benzie, J. (2004). Slow Growth and Lack of Recovery in Overfished Holothurians on the Great Barrier Reef: Evidence from DNA Fingerprints and Repeated Large-Scale Surveys. Conservation Biology, 18, 1395-1404. https://doi.org/10.1111/j.1523-1739.2004.00309.x

Uthicke, S., Byrne, M., \& Conand, C. (2010). Genetic barcoding of commercial Bêche-de-mer species (Echinodermata: Holothuroidea). Molecular Ecology Resources, 10. doi: 10.1111/j.1755-0998.2009.02826.x

Venkataraman, C. (2007). Present status of population of holothurians in India. FAO-BOBLME. 58.

Vergara-Chen, C., González-Wangüemert, M., Marcos, C., \& Perez-Ruzafa, A. (2010). Genetic diversity and connectivity remain high in Holothuria polii (Delle Chiaje 1823) across a coastal lagoon-open sea environmental gradient. Genetica, 138, 895-906. doi: 10.1007/s10709010-9472-x

Veronika, K., Edrisinghe, U., Sivashanthini, K., \& Athauda, A. (2016). Abundance and diversity of sea cucumbers in point pedro coastal waters in Jaffna peninsula of Sri Lanka. Tropical agricultural research, 27, 182. doi:10.4038/tar.v27i2.8166

Veronika, K., Edrisinghe, U., Sivashanthini, K., \& Athauda, A. (2017). Present status of holothurian fisheries in mullaitivu coastal waters in North-East region of Sri Lanka. Tropical agricultural research, 28, 216.

Veronika, K., Edrisinghe, U., Sivashanthini, K., \& Athauda, A. (2018). Length-weight relationships of four different sea cucumber species in North-East coastal region of Sri Lanka. Tropical agricultural research, 29, 212-217. doi: 10.4038/tar.v29i2.8290

Watanabe, S., Zarate, J.M., Lebata-Ramos, M.J., \& Nievales, M.F. (2012). Evaluation of nutritional condition of juvenile sandfish (Holothuria scabra). Proceedings of the international symposium of Asia-Pacific tropical sea cucumber aquaculture, ACIAR, Noumea, New Caledonia, $15^{\text {th }}-17^{\text {th }}$ February 2011; Hair C.A., Pickering T.D., Mills D.J. Eds. No. 136, 50-56, pp 209, Australian Centre for International Agricultural Research: Canberra.

Kazanidis, G., Antoniadou, C., Lolas, A., Neofitou, N., Vafidis, D., Chintiroglou, C., \& Neofitou, C. (2010). Population dynamics and reproduction of Holothuria tubulosa (Holothuroidea: Echinodermata) in the Aegean Sea. Journal of the Marine Biological Association of the United Kingdom, 90, 895-901. https://doi.org/10.1017/S0025315410000251 